\title{
HUBUNGAN AGENSI DAN KINERJA PADA PERUSAHAAN KELUARGA DI INDONESIA
}

\author{
D. Agus Harjito \\ Jurusan Manajemen, Fakultas Ekonomi \\ Universitas Islam Indonesia, Yogyakarta, Indonesia \\ e-mail: agus_h@uii.ac.id; harjitok@yahoo.com
}

\begin{abstract}
The objective of this study is to investigate the simultaneous relationship between managerial ownership, institutional ownership, debt policy and dividend policy in reducing agency problem mechanism in the Family Business in Indonesia. If there is a negative relationship between the mechanisms of reducing agency problems means there is an interchangeable (substitution) relationship between the mechanisms of reducing the agency problems that agency costs can be reduced. However, if there is a positive relationship means that the increasing use of one of the mechanisms reducing agency problems will increase the use of other mechanism reducing agency problems. The populations of this study are all companies listed on the Indonesia Stock Exchange from 2001 to 2011 except for companies from the financial sector, banking, and the dominant firm is owned by the government. The sample in this study are 46 companies that obtained by the method of purposive sampling. To analyze the relationship between variables simultaneously, this study uses two-stage least squares (2SLS). The result shows that there is significant relationship exists between debt policy and dividend policy. But, there is no significant relationship between insider ownership and debt policy, and between insider ownership and dividend policy in reducing agency problems in the Family Business in Indonesia although the firm performances proxied by Tobin's $Q$ are increase.
\end{abstract}

Keywords: agency problems, firm performance and family business.

\begin{abstract}
Abstrak
Penelitian ini bertujuan untuk mengkaji hubungan agensi yang ditunjukkan oleh variabel-variabel pengawasan masalah agesi dengan kinerja pada perusahaan keluarga di Indonesia. Variabelvariabel pengawasan masalah agensi yang digunakan sebagai variabel dependen dan sekaligus juga sebagai variabel independen meliputi kebijakan hutang, kepemilikan insider dan kebijakan dividen, sedangkan kinerja perusahaan keluarga diproksi dengan nilai Tobin's $Q$ yaitu nilai yang diperoleh dari hasil bagi antara nilai buku total hutang ditambah nilai pasar ekuitas dibagi dengan nilai buku total aset. Adapun variabel independen lainnya yang digunakan meliputi kepemilikan institusi, risiko bisnis, ukuran perusahaan, tingkat profitabilitas, dan tingkat pertumbuhan. Jumlah populasinya sebanyak 59 perusahaan keluarga, sedangkan jumlah sampel penelitian sebanyak 46 perusahaan keluarga yang sudah go public atau terdaftar di Bursa Efek Indonesia mulai tahun 2001 sampai 2011. Data dianalisis dengan metode Two-Stage Least Square (2SLS). Hasil penelitian menunjukkan bahwa terdapat hubungan substitusi yang signifikan antara kebijakan hutang dan kebijakan dividen dalam peranan mekanisme pengawasan masalah agensi pada perusahaan keluarga di Indonesia. Sementara itu, tidak ada hubungan substitusi antara kebijakan hutang dan kepemilikan insider, dan tidak ada hubungan substitusi antara kepemilikan insider dan kebijakan dividen dalam peranan mekanisme pengawasan masalah agensi. Terakhir, disimpulkan bahwa kebijakan hutang memiliki hubungan yang positif dan signifikan dengan kinerja perusahaan, sedangkan kepemilikan insider dan kebijakan dividen tidak memiliki hubungan yang signifikan dengan kinerja perusahaan keluarga di Indonesia.
\end{abstract}

Kata Kunci: hubungan agensi, kinerja perusahaan, perusahaan keluarga. 


\section{PENDAHULUAN}

Masalah agensi terjadi apabila ada konflik kepentingan antara pemilik (pemegang saham) dengan manajer perusahaan (Morck dan Yeung, 2003). Hal ini karena dalam melakukan tugasnya manajer perusahaan tidak memenuhi seluruh kepentingan pemegang saham, bahkan mereka menggunakan fasilitas perusahaan untuk kepentingan pribadi. Keadaan seperti itu yang menyebabkan munculnya masalah agensi di perusahaan tersebut. Munculnya masalah agensi menimbulkan biaya agensi yang meliputi biaya pengawasan, biaya ikatan (bonding) dan biaya residual (Jensen dan Meckling, 1976). Biaya pengawasan muncul apabila pemilik perusahaan melakukan pengawasan terhadap kegiatan yang dilakukan oleh manajer (pihak manajemen). Adapun bonding cost merupakan biaya yang timbul ketika manajer memastikan untuk bekerja berdasarkan kontrak yang telah disetujui bersama prinsipal. Biaya residual merupakan biaya kesempatan yang muncul karena adanya perbedaan return yang diperoleh oleh perusahaan karena perbedaan keputusan investasi antara manajer dan prinsipal. Dengan demikian biaya kesempatan yang dimaksud adalah kesempatan "yang hilang" ketika suatu keputusan diambil.

Berbagai variabel yang dapat mengurangi masalah atau konflik agensi meliputi peningkatan penggunaan hutang, kepemilikan insider, kepemilikan institusional dan pembayaran dividen. Peningkatan penggunaan hutang dapat mengurangi konflik agensi antara manajer dengan pemegang saham (Morck dan Yeung, 2003). Hutang akan mengurangi aliran kas bebas (free cash flow), karena perusahaan harus membayar bunga atas hutang tersebut. Berkurangnya aliran kas tesebut menyebabkan berkurangnya uang yang ada di perusahaan, seingga membatasi keinginan manajer menggunakan aliran kas tersebut. Sementara itu, pemegang saham menghendaki aliran kas tersebut supaya dapat dibagikan sebagai dividen untuk menambah kekayaan mereka atau diinvestasikan kembali ke dalam proyekproyek yang menghasilkan returpositif.

Pengurangan konflik agensi dapat dilakukan dengan meningkatkan kepemilikan insider. Meningkatnya kepemilikan insider akan menyebabkan kesesuaian (alignment) kepentingan antara manajer dengan pemilik.
Semakin besar tingkat kepemilikan insider, maka semakin tinggi tingkat kesesuaian kepentingan manajer dan pemilik perusahaan (Jensen dan Meckling, 1976; Maury, 2005). Dengan demikian maka konflik yang terjadi antara manajer dan pemilik perusahaan akan berkurang.

Pembayaran dividen yang tinggi sangat diharapkan oleh para pemegang saham. Pendapatan dividen ini merupakan return yang diharapkan oleh investor. Oleh karena itu, peningkatan pembayaran dividen adalah sesuai dengan tuntutan pemegang saham, sehingga peningkatan dividen ini dapat mengurangi masalah agensi antara pemegang saham dengan manajer karena keinginan pemegang saham sudah sesuai dengan tindakan manajer untuk meningkatkan pembayaran dividen ini (Borokhovich et al. 2005). Namun demikian, kebijakan pembayaran dividen untuk mengurangi masalah agensi menimbulkan masalah baru karena dana untuk membayar dividen perlu diganti agar uang kas tetap tersedia di dalam perusahaan.

Sesuai penjelasan tersebut di atas, maka ketiga variabel yaitu kebijakan hutang, kepemilikan insider dan kebijakan dividen bertindak sebagai variabel mekanisme pengawasan untuk mengurangi masalah agensi. Dalam pengawasan masalah agensi ini, ketiga variabel tersebut dapat bertindak secara tersendiri maupun secara serentak. Hal ini berarti bahwa mekanisme pengawasan dapat dilakukan oleh setiap variabel secara sendiri-sendiri atau saling bersama-sama.

\section{KAJIAN PUSTAKA}

Pada umumnya, banyak orang memberikan pengertian perusahaan keluarga dengan mengkonotasikannya sebagai perusahaan kecil dan menengah. Hal ini wajar saja karena perusahaan kecil dan menengah biasanya dikelola oleh keluarga. Namun demikian, kenyataannya perusahaan keluarga termasuk juga perusahaan yang berskala besar dan sudah go public. Biasanya, mula-mula perusahaan keluarga didirikan oleh seorang wirausaha atau entrepreneur dengan tujuan untuk memenuhi kebutuhan hidupnya. Namun ada juga yang beralasan untuk memenuhi atau menyalurkan hobi mereka atau karena alasan lainnya, seperti untuk mencari tambahan penghasilan, mencip- 
takan lapangan kerja bagi dirinya sendiri, keluarga dan teman-teman, dan meninggalkan warisan bagi keluarga mereka. Semua alasanalasan tersebut merupakan pendorong utama munculnya perusahaan keluarga. Oleh karena itu, berdirinya perusahaan keluarga merupakan konsekuensi dari perilaku kewirausahaan para pendiri yang menemukan adanya peluang bisnis, sehingga orientasi kewirausahaan mereka harus dipertahankan dan ditingkatkan oleh generasi berikutnya. Generasi penerus tersebut melanjutkan dan mengembangkannya, sehingga perusahaan keluarga tersebut berkembang terus demi mewujudkan kesejahteraan keluarga seluruh ahli warisnya. Biasanya, jangka waktu lamanya rentang hidup perusahaan keluarga generasi pertama rata-rata selama sekitar 20 hingga 30 tahun. Chen et al. (2006) juga menemukan bahwa prestasi yang diperoleh oleh para pendiri perusahaan keluarga nampaknya mulai menurun bahkan gagal setelah perusahaan tersebut dipegang oleh generasi berikutnya. Meskipun demikian, banyak juga yang mencapai kesuksesan pada generasi kedua dan ketiga. Para penerus perusahaan keluarga dituntut untuk berprestasi dan berinovasi mengekspresikan dan mengimplementasikan ide-ide barunya agar prestasi yang telah dicapai oleh para pendiri bisnis dapat dilanjutkan.

Perusahaan keluarga tidak hanya berkonotasi bagi perusahaan kecil dan menengah saja. Perusahaan besar dan sudah go publie pun banyak yang dimiliki oleh keluarga. Penelitian ini terutama juga mengkaji perusahaan-perusahaan keluarga yang sudah go public di Bursa Efek Indonesia. Seperti halnya perusahaan yang sudah go public, perusahaan keluarga yang sudah go public juga terdapat pemisahan antara pemilik dan manajer (manajemen). Tujuan pemisahan antara kepemilikan perusahaan dengan pengawasan dalam sesuatu kontrak (antara prinsipal dengan agen) adalah untuk mencapai keefisienan perusahaan tersebut (Fama 1980). Di samping itu, bentuk pemisahan antara kepemilikan dan pengawasan dalam perusahaan keluarga telah menimbulkan perkembangan strategi untuk mencapai keefisienan perusahaan dengan memperhatikan masalah insentif untuk manajer yang bukan pemilik perusahaan. Insentif ini diberikan oleh prinsipal pada manajer agar keputusan yang diambil oleh manajer sesuai dengan kepen- tingan mereka. Namun demikian, manajer juga memiliki kepentingan yang berbeda dengan pemegang saham (Schulze et al, 2001), sehingga kemungkinan keputusan yang diambil oleh manajer tidak sesuai dengan kepentingan pemegang saham yang dapat menimbulkan masalah agensi antara pemegang saham dan manajer perusahaan, khususnya perusahaan keluarga.

Mekanisme pengawasan masalah agensi di perusahaan telah diteliti oleh banyak peneliti. Namun demikian, penelitian terdahulu menunjukkan berbagai hasil yang tidak konsisten dan bersifat final (Miguel et al. 2005; Harjito dan Nurfauziah, 2006). Sementara itu, masalah agensi di perusahaan keluarga belum banyak diteliti khususnya di Indonesia. Mork and Yeung (2003) meneliti tetang masalah agensi di grup perusahaan keluarga di Amerika Serikat dan Inggris. Mereka menemukan bahwa semakin besar insider ownership (kepemilikan insider) semakin baik dalam tata kelolanya (corporate governance). Masalah agensi kemungkinan dapat diminimalisir dengan dikontrol oleh kepemilikan keluarga. Kepemilikan insider akan mengontrol manajer agar mencapai kinerja perusahaan sesuai dengan yang diharapkan oleh pemilik. Di samping itu, masalah agensi juga dapat dikurangi dengan peningkatan hutang dan pembayaran dividen. Meningkatnya hutang akan mengurangi proporsi kepemilikan, sehingga konflik atau masalah agensi akan berkurang. Meningkatnya hutang juga akan mengurangi keuntungan perusahaan yang pada akhirnya akan mengurangi aliran kas bebas (free cash flow) sebagai aliran kas yang dapat menyebabkan konflik agensi. Akhirnya, masalah agensi dapat dikurangi dengan meningkatnya pembayaran dividen kepada pemegang saham atau pemilik. Semakin besar dividen yang dibayarkan kepada pemilik perusahaan, maka mereka akan semakin makmur sehingga tujuan para pemegang saham tersebut semakin terpenuhi kebutuhannya sehingga konflik agensinyapun semakin berkurang (Jensen dan Meckling, 1976). Ketiga mekanisme tersebut (peningkatan kepemilikan insider, peningkatan hutang dan peningkatan pembayaran dividen) akan saling berhubungan dalam proses mekanisme pengawasan masalah agensi di perusahaan baik perusahaan keluarga maupun perusahaan non keluarga. 


\section{Tinjauan Hubungan Agensi}

Hubungan antara pemilik perusahaan (pemegang saham) dengan manajernya merupakan hubungan agensi yang muncul karena adanya pemisahan antara wewenang dan tanggungjawab dalam perusahaan. Menurut Jensen dan Meckling (1976), hubungan agensi sebagai suatu kontrak antara seorang atau lebih pemegang saham (prinsipal) yang meminta orang lain sebagai pengelola untuk melaksanakan beberapa pekerjaan bagi kepentingan prinsipal untuk membuat keputusan. Namun dalam pelaksanaannya pengelola atau manajer tidak seratus persen bertindak sesuai dengan kepentingan prinsipal, sehingga menimbulkan konflik kepentingan yang dinamakan konflik atau masalah agensi. Konflik ini dapat terjadi karena adanya perbedaan informasi diantara mereka sehingga menyebabkan pengambilan keputusanyapun berbeda. Pihak manajer sebagai agen mempunyai lebih banyak informasi tentang kemampuan dan risiko perusahaan, sedangkan pihak pemegang saham (prinsipal) hanya mengetahui sedikit masalah yang terjadi di dalam perusahaan dan secara keseluruhan tidak memahami keputusan yang dibuat oleh pihak manajemen (Schulze et al, 2001).

Adanya perbedaan kepentingan diantara manajer dan pemilik perusahaan mendorong agen (manajer) untuk melakukan tindakan sesuai dengan kemauan pribadi yang merugikan pemilik atau prinsipal. Untuk itu dibuat kontrak yang menetapkan kontrak hubungan mereka untuk mencapai tujuan perusahaan yang diinginkan. Perbedaan kepentingan tersebut berakibat terjadinya ketidakefisienan dalam proses pembuatan keputusan (Jensen, 1986), sehingga keputusan yang diambil dapat keliru dan bertentangan (adverse selection) dengan rencana yang diinginkan.

Jensen dan Meckling (1976) mengatakan bahwa masalah agensi akan muncul apabila manajer memiliki saham perusahaan kurang dari 100 persen. Keadaan ini menyebabkan manajer memindahkan sebagian biaya pembuatan keputusan untuk kepentingan mereka sendiri pada pemegang saham lain (Yong, 1997). Ketika manajer membuat sesuatu keputusan yang berkait dengan kepentingan manajer, maka biaya yang timbul akibat keputusan tersebut dibebankan juga pada pemegang saham sebagai pemilik perusahaan. Masalah agensi tersebut tidak dapat hanya diselesaikan melalui kontrak berdasarkan aliran kas dan pengeluaran investasi saja (Harris dan Raviv, 1990). Namun, mereka menyatakan bahwa peningkatan kepemilikan insider dan penerbitan hutang juga dapat untuk mengurangi masalah agensi. Selanjutnya, Jensen (1986) menyatakan bahwa kebijakan penerbitan hutang juga dapat digunakan sebagai alat untuk mendisiplinkan manajer karena manajer harus bekerja lebih keras untuk membayar kembali hutang dan bunganya. Akhirnya, pembayaran dividen yang tinggi dapat mengurangi konflik agensi karena pembayaran dividen merupakan salah satu tujuan para pemegang saham.

Hubungan dan konflik agensi juga terjadi antara pemegang saham dengan pemegang hutang disebabkan oleh perbedaan sikap prinsipal dan agen terhadap risiko bisnis (Jensen dan Smith, 1985; Schulze et al, 2001). Mereka menjelaskan bahwa pemegang saham dapat membuat keputusan untuk memindah kekayaan dari pemegang hutang pada mereka. Semakin besar rasio hutang pada ekuitas, keuntungan semakin besar dan pemegang saham dapat mengawal perusahaan untuk melakukan proyek berisiko. Sementara itu, pemegang hutang akan menuntut return yang lebih besar dari hutang mereka.

Myers (1977) menyatakan bahwa hubungan agensi antara pemegang saham dan pemegang hutang akan menimbulkan under investment. Masalah lain akan muncul apabila sebuah perusahaan mempunyai kebebasan melakukan investasi. Apabila manajer mempunyai keleluasaan yang lebih dalam investasi, mereka kemungkinan melakukan investasi tersebut yang manfaat utamanya adalah untuk meningkatkan kekayaan pemegang obligasi di atas kekayaan pemegang saham. Sedangkan penelitian yang dilakukan oleh Douglas (2002) menemukan bahwa konflik antara pemegang saham dan pemegang hutang akan menimbulkan masalah under-investment. Dengan tingkat hutang yang berisiko rendah, maka hubungan agensi tidak muncul tetapi pengawasan pada manajer lebih pada bentuk reward yang diberikan. Sedangkan pada hutang yang berisiko tinggi, pemegang saham memfokuskan pada return yang tinggi sehingga biaya agensi antara pemegang saham dan pemegang hutang meningkat tetapi biaya reward untuk manajer menurun. 


\section{Mekanisme Pengawasan Masalah Agensi}

Perusahaan selalu berusaha untuk meurangi masalah agensi yang terjadi. Kinerja perusahaan akan meningkat apabila masalah agensi ini dapat diatasi atau dikurangi. Kajian yang dilakukan oleh Jensen dan Meckling (1976) menyimpulkan bahwa masalah agensi yang terjadi di suatu perusahaan dapat dikurangi dengan melakukan pengawasan, pemberian insentif, meningkatkan kepemilikan manajer (kepemilikan insider) dan melakukan tindakan ikatan (bonding) bagi manajer. Mekanisme pengawasan dilakukan oleh pihak prinsipal atas kegiatan yang dilakukan oleh manajer sebagai agen. Sedangkan peningkatan kepemilikan insider dimaksudkan agar terjadi kesesuaian (alignment) antara kepentingan prinsipal dan manajer. Sementara itu, mekanisme ikatan dilakukan dengan meningkatkan pembayaran dividen dan jumlah hutang. Semua mekanisme tersebut di atas berpotensi menimbulkan biaya yang dapat menurunkan nilai perusahaan yang disebut biaya agensi. Kajian lain yang dilakkan oleh Jensen (1986) menemukan mekanisme pengawasan masalah agensi adalah dengan mengurangi aliran kas bebas. Dana yang dapat disalah gunakan oleh manajer dibatasi jumlahnya sehingga masalah agensi menjadi kecil. Usaha mengurangi aliran kas bebas dapat dilakukan dengan cara meningkatkan hutang dan pembagian kas pada pemegang saham baik melalui pembayaran dividen maupun pembelian kembali saham.

Selanjutnya Jensen (1986) dalam hipotesis aliran kas bebas tersebut menunjukkan bahwa apabila aliran kas bebas terlalu banyak maka masalah agensi akan lebih buruk. Hal ini disebabkan karena manajer perusahaan yang mempunyai kelebihan aliran kas akan menggunakan dana itu untuk aktivitas yang tidak mempunyai manfaat langsung terhadap kinerja keuangan. Oleh karena itu, prinsipal perlu memperhatikan dan memotivasi manajer untuk menggunakan kelebihan aliran kas yang tersedia dengan cara yang lebih menguntungkan. Di sisi lain, manajer perlu mengurangi penggunaan kelebihan aliran kas bebas tersebut yang biasanya digunakan untuk proyek yang menghasilkan tingkat return (rate of return) lebih rendah dari biaya modal atau penggunaan secara tidak efisien. Manajer perlu menggunakan aliran kas bebas sesuai dengan kepentingan prinsipal yaitu kegiatan yang akan meningkatkan kinerja perusahaan.

\section{Hubungan Substitusi dalam Mekanisme Pengawasan Masalah Agensi}

Literatur tata kelola perusahaan menunjukkan bahwa mekanisme pengawasan masalah agensi dalam sebuah perusahaan mempertimbangkan manfaat dan biaya yang terjadi. Jensen dan Meckling (1976) menyatakan bahwa struktur kepemilikan, kebijakan hutang dan dividen berhubungan erat dalam menyelesaikan masalah agensi yang ada karena konflik kepentingan antara prinsipal dengan agen. Mereka menemukan bahwa kepemilikan insider mempunyai hubungan substitusi dengan kebijakan dividen dalam mekanisme pengawasan masalah agensi. Hubungan substitusi ini ditunjukkan oleh hubungan negatif antara kepemilikan insider $\mathrm{d}$ an kebijakan dividen. Selanjutnya, mereka menegaskan bahwa perusahaan melakukan penggantian kebijakan dividen dengan kepemilikan insider untuk mengawal biaya agensi yang timbul. Oleh karena itu, perusahaan yang menggunakan kebijakan dividen untuk mengawal masalah agensi dapat mengurangi peranan kepemilikan insider untuk tujuan yang sama.

Friend dan Lang (1988) menyatakan bahwa kepemilikan insider mempunyai hubungan terbalik atau negatif dengan kebijakan hutang. Dalam konteks pengawasan masalah agensi, hubungan terbalik atau negatif berarti sebagai hubungan substitusi dalam peranan pengawasan masalah agensi. Kepemilikan insider yang tinggi mempunyai kemampuan pengawasan yang tinggi pada manajer ketika menjalankan perusahaan karena kepemilikan insider dapat menyelaraskan antara kepentingan prinsipal dengan agen. Kepemilikan insider yang tinggi cenderung menurunkan penggunaan hutang. Hutang yang tinggi akan meningkatkan risiko kebangkrutan dan kesulitan keuangan. Oleh karena itu, apabila kedua kepemilikan insider dan hutang mempunyai hubungan substitusi maka perusahaan yang mempunyai kepemilikan insider yang tinggi cenderung mengurangi penggunaan hutang untuk meminimalkan biaya agensi yang pada akhirnya akan mengurangi masalah agensi. 
Hubungan negatif antara kebijakan hutang dengan dividen dikemukakan oleh Jensen et al. (1992). Mereka menyatakan bahwa peningkatan pembayaran dividen akan mengurangi pembiayaan dari dalam perusahaan. Perusahaan akan memperoleh modal baru dari investor luar. Peningkatan investor baru akan meningkatkan pengawasan terhadap manajer sehingga masalah agensi dapat dikurangi. Di samping itu, pembayaran dividen akan mengurangi aliran kas bebas yang dikendalikan manajer. Selanjutnya akan mengurangi wewenang manajer menggunakan aliran kas bebas untuk keperluan yang tidak sesuai dengan kepentingan pemegang saham. Sebaliknya, penggunaan hutang yang tinggi akan mengurangi pembayaran dividen dan aliran kas bebas sehingga masalah agensi dapat dikurangi. Oleh karena itu, hubungan negatif yang terjadi antara kebijakan hutang dengan dividen dapat dikatakan sebagai hubungan substitusi. Hal ini berarti bahwa apabila peranan hutang dalam pengawasan masalah agensi meningkat maka peranan dividen dapat dikurangi dan terjadi sebaliknya.

Penelitian tentang mekanisme pengawasan masalah agensi setuju terhadap adanya hubungan antara setiap variabel dalam mekanisme pengawasan tersebut. Namun demikian, jenis hubungan yang terjadi belum final sebagai bukti hubungan substitusi atau hubungan saling melengkapi dalam peranan pengawasan masalah agensi (Miguel et al. 2005). Hubungan substitusi menunjukkan bahwa apabila satu mekanisme adalah keras, maka mekanisme yang lain akan menjadi kurang bermanfaat. Sedangkan, hubungan saling melengkapi menunjukkan bahwa antara satu mekanisme dengan satu mekanisme yang lain adalah saling melengkapi. Apabila peranan pengawasan satu mekanisme meningkat, maka peranan pengawasan mekanisme yang lain juga akan meningkat sebagai penyelesaian yang paling efektif untuk masalah agensi yang terjadi dalam sebuah perusahaan. Sebaliknya, apabila peranan pengawasan suatu mekanisme menurun maka peranan pengawasan mekanisme yang lain juga berkurang.

Kemampuan substitusi dari kepemilikan insider, hutang dan dividen dalam peranan pengawasan masalah agensi telah diterapkan oleh kebanyakan perusahaan di Amerika Serikat. Crutchley dan Hansen (1989) menganalisis apakah perusahaan memilih kebijakan campuran dari kepemilikan manajer, leverage dan dividen untuk melakukan pengawasan masalah agensi. Dengan pemilihan mekanisme pengawasan yang biasa digunakan, perusahaan dapat mengenal hubungan yang terjadi antara setiap mekanisme tersebut. Penelitian mereka memfokuskan pada masalah bagaimana manajer perusahaan secara serentak membuat ketiga mekanisme pengawasan dapat substitusi dan mengambil manfaat dari setiap mekanisme tanpa terjadi tambahan biaya.

Bathala et al. (1994) secara serentak mengkaji keadaan saling bergantung dari kepemilikan insider, kebijakan hutang, dan kepemilikan institusi. Penelitian mereka menggunakan kepemilikan insider dan kebijakan hutang sebagai variabel endogen, sedangkan kepemilikan institusi dan variabel lain seperti volatilitas return (earning volatility), pengadaan aset tidak berwujud, pertumbuhan aset, dan kepemilikan manajer sebagai variabel eksogen. Kebijakan dividen yang sering digunakan dalam mekanisme pengurangan masalah agensi tidak diteliti. Mereka menemukan bahwa kepemilikan insider dapat membantu untuk kesesuaian kepentingan antara pemegang saham yang bukan manajer dengan kepemilikan insider. Sumbangan utama hasil penelitian mereka adalah penjelasan bahwa peningkatan kepemilikan insider mengurangi masalah agensi ekuitas.

\section{Hubungan Agensi dan Kinerja Perusahaan}

Kepemilikan insider menjadikan kesesuaian kepentingan antara manajer dengan pemegang saham (prinsipal). Kesesuaian kepentingan ini mewujudkan suasana kerja yang serasi sehingga manajer akan lebih mudah untuk mencapai tujuan perusahaan yaitu meningkatkan kinerja (nilai) perusahaan (Jensen dan Mekcling 1976). Hal ini dapat memberikan hubungan yang positif antara kepemilikan manajer dengan kinerja perusahaan. Hubungan tersebut telah diperkenalkan oleh James Tobin tahun 1969 yang sering disebut sebagai Tobin's Q. Nilai Tobin's Q ini menunjukkan rasio $Q$, yaitu rasio antara nilai pasar dengan nilai buku (market to book ratio) yang dihitung dari rasio harga pasar ekuitas perusahaan ditambah hutang dibagi nilai aset perusahaan disesuaikan dengan inflasi dan penyusutan (Pomerleano, 1998). Dengan rasio Q 
ini dapat digunakan untuk mengukur apakah perusahaan memiliki nilai pasar yang lebih besar dari nilai bukunya atau tidak. Apabila rasio Q lebih dari 1 artinya manajer sudah menambah nilai untuk pemegang saham, sedangkan nilai Tobin's Q lebih rendah dari 1 menunjukkan bahwa nilai perusahaan telah berkurang dari nilai bukunya. Oleh karena itu, rasio Q memberikan tanda (signal) kepada pasar atau para investor yang ingin melakukan investasi pada suatu perusahaan tertentu yang diketahui nilai Tobin's Q-nya.

Penelitian ini menggunakan konsep nilai Tobin's Q untuk digunakan sebagai ukuran penilaian untuk menyelidiki hubungan antara kebijakan hutang, kepemilikan insider, kebijakan dividen dan nilai perusahaan keluarga di Indonesia dengan alasan bahwa Tobin's Q merupakan pengukur yang telah banyak digunakan oleh banyak peneliti baik praktisi maupun para akademisi sebagai formula yang menggunakan informasi yang ada di laporan keuangan. Pada dasarnya, definisi Tobin's Q menunjukkan pada dua konsep yaitu konsep peluang pertumbuhan dan konsep kinerja perusahaan (Pomerleano, 1998). Konsep peluang pertumbuhan memfokuskan pada harapan pasar terhadap nilai suatu proyek di masa depan yang sudah diharapkan oleh manajer. Sedangkan konsep kinerja perusahaan menunjukkan pada pengukuran kinerja perusahaan terhadap aset yang digunakan untuk memperoleh return yang telah ditetapkan.

Nilai Tobin's Q ini mempunyai peranan yang penting dalam penilaian kinerja keuangan dan telah digunakan untuk menjelaskan sejumlah fenomena yang terjadi di sebuah per- usahaan. Chen dan Steiner (2000) berusaha untuk membuat model empiris yang sesuai dan signifikan untuk melihat hubungan antara analyst coverage, kepemilikan manajer dan Tobin's Q. Harjito (2006) menggunakan Tobin's Q sebagai proksi nilai perusahaan untuk melihat hubungan substitusi antara mekanisme pengawasan masalah agensi perusahaan-perusahaan di Malaysia. Hasil kajiannya menunjukkan bahwa apabila terjadi hubungan substitusi diantara mekanisme pengawasan masalah agensi (kebijakan peningkatan insider ownership, kebijakan hutang dan kebijakan dividen, maka kinerja perusahaan akan meningkat.

Dari penjelasan hubungan antara kebijakan hutang, kepemilikan insider, dan pembayaran dividen, penelitian ini menyatakan hipotesis berikut ini:

H1: Terdapat hubungan substitusi yang siginifikan antara kebijakan hutang dengan kepemilikan insider dalam peranan pengawasan masalah agensi pada perusahaan keluarga yang ditunjukkan dengan meningkatnya kinerja perusahaan.

H2: Terdapat hubungan substitusi yang signifikan antara kebijakan hutang dengan kebijakan pembayaran dividen dalam peranan pengawasan untuk mengurangi masalah agensi pada perusahaan keluarga yang ditunjukkan dengan meningkatnya kinerja perusahaan.

H3: Terdapat hubungan substitusi antara kepemilikan insider dengan pembayaran dividen dalam peranan pengawasan untuk mengurangi masalah agensi pada perusahaan keluarga yang ditunjukkan dengan meningkatnya kinerja perusahaan.

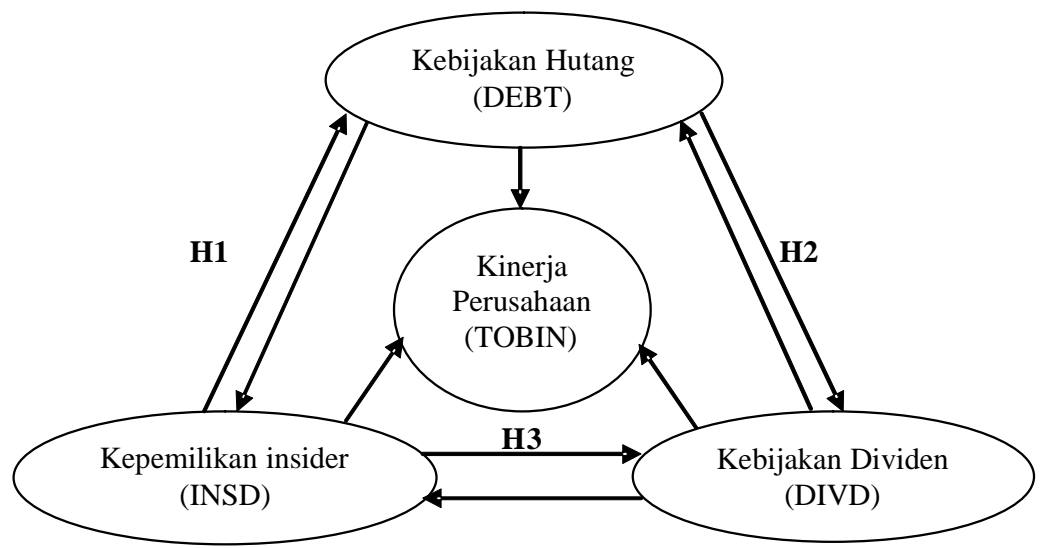

Gambar 1: Hubungan substitusi antara hutang, kepemilikan insider dan dividen dan pengaruhnya pada kinerja perusahaan keluarga 


\section{METODE PENELITIAN Populasi dan Sampel}

Populasi dari penelitian ini meliputi semua perusahaan keluarga yang telah go public atau terdaftar di Bursa Efek Indonesia (BEI) pada tahun 2001 hingga tahun 2011. Pemilihan populasi tersebut untuk melihat apakah penelitian- penelitian terdahulu, baik penelitian yang dilakukan di luar negeri maupun di Indonesia, tetap konsisten jika populasi yang dipilih dikhususkan untuk perusahaan keluarga yang ada di Indonesia. Penelitian-penelitian terdahulu di Indonesia mengenai permasalahan agensi pada umumnya memilih populasi dari seluruh perusahaan manufaktur di Bursa Efek Jakarta. Perusahaan keluarga juga tidak dipisahkan secara rinci, sehingga hasil penelitian masih bersifat umum bagi perusahaanperusahaan keluarga yang go public di Bursa Efek Indonesia.

Sampel yang diambil tentu saja dari perusahaan-perusahaan keluarga yang sudah $g o$ public di Bursa Efek Indonesia. Jumlah perusahaan keluarga yang sudah terdaftar di BEI sebanyak 59 perusahaan. Dari jumlah tersebut diambil sampel yang memenuhi syarat atau kriteria tertentu sebanyak 46 perusahaan. Pengambilan sampel menggunakan metode purposive sampling (sampel sengaja dipilih agar dapat mewakili populasinya dan dapat memenuhi tujuan penelitian) berdasarkan kriteria-kriteria yang meliputi, 1) Perusahaan merupakan perusahaan keluarga yang terdaftar di Bursa Efek Indonesia dari tahun 2001 hingga 2011. 2) Perusahaan harus memiliki kebijakan hutang baik hutang jangka pendek maupun hutang jangka panjang. 3) Perusahaan berkenaan memiliki data kepemilikan insider dari tahun 2001 hingga tahun 2011 yang dilaporkan pada publik. 4) Perusahaan berkenaan telah membayar dividen sesuai peraturan yang ada. Apabila perusahaan tersebut tidak membayar dividen pada tahun tertentu, dividen dapat dibayar pada tahun yang lain dan dilaporkan dalam laporan keuangan.

\section{Pengumpulan Data}

Penelitian ini menggunakan data sekunder yaitu informasi dari laporan keuangan perusahaan keluarga dari berbagai sektor yang terdaftar di Bursa Efek Indonesia dari tahun 2001 hingga tahun 2011. Semua data yang diperlukan dalam penelitian ini diperoleh dari Datastream, Indonesia Capital Maket Directory dan Laporan Tahunan dari tahun 2001 sehingga 2011. Perusahaan keluarga yang dijadikan sampel adalah semua perusahaan keluarga yang sudah go public dan bergerak di semua bidang, baik di bidang keuangan maupun non keuangan. Oleh karena itu, perusahaanperusahaan keluarga yang dijadikan sampel adalah perusahaan keluarga yang bergerak di bidang manufaktur dan jasa.

\section{Variabel Penelitian}

Penelitian ini menggunakan 4 (empat) variabel tergantung (dependen) dan 6 (enam) variabel tidak tergantung atau variabel bebas (independen) untuk membuktikan hopotesis yang diusulkan sebagaimana telah digunakan oleh Harjito dan Nurfauziah (2006). Variabel tergantung adalah rasio hutang (DEBT), kepemilikan insider atau kepemilikan manajerial (INSD), dividen (DIVD). Ketiga variabel tergantung tersebut juga bertindak sebagai variabel bebas. Sementara nilai perusahaan keluarga diproksi dengan nilai Tobin's Q (TOBIN), sedangkan variabel yang hanya bertindak sebagai variabel tidak tergantung terdiri dari kepemilikan institusi (INST), aktiva tetap (FASET), ukuran perusahaan (SIZE), risiko bisnis (RISK), tingkat pertumbuhan (GROWTH), dan tingkat keuntungan (PROFIT). Variabel nilai perusahaan yang diproksi oleh Tobin's $Q$ tesebut di atas digunakan untuk mengetahui pengaruh berkurangnya masalah agensi dari hubungan substitusi di antara setiap mekanisme pengawasan. Apabila terjadi hubungan substitusi diantara mekanisme pengawasan masalah agensi, maka masalah agensi tersebut akan berkurang. Berkurangnya masalah agensi akan meningkatkan proses produksi serta kegiatan lain di perusahaan dan pada akhirnya nilai perusahaan akan meningkat. Oleh karena itu, berkurangnya masalah atau konflik agensi ini akan meningkatkan kinerja atau performance perusahaan.

Terdapat masalah endogeniti dalam model penelitian ini, yaitu masalah yang muncul karena suatu variabel dalam suatu persamaan bertindak sebagai variabel dependen (endogen), tetapi dalam persamaan yang lain variabel tersebut bertindak sebagai variabel independen (eksogen). Untuk menyelesaikan permasalahan endogeniti tersebut maka 
digunakan model persamaan serentak atau simultan yaitu Metode Kuadrat Terkecil Dua Tahap (Two-Stage Least Squares, 2SLS). Sebenarnya metode ini didasarkan juga pada asumsi metode Ordinary Least Square (OLS). Pada model persamaan simultan ini variabel tergantung pada suatu persamaan akan muncul sebagai variabel bebas pada persamaan yang lain dan biasanya berkorelasi dengan unsur gangguan dari persamaan di mana variabel tadi muncul sebagai variabel yang menjelaskan (Gujarati, 2003).

\section{Metode Analisis Data}

Diungkapkan sebelumnya bahwa untuk menganalisis hubungan substitusi antara ketiga mekanisme pengurang masalah agensi digunakan persamaan serentak 2SLS. Berkurangnya masalah agensi dalam perusahan keluarga ditunjukkan dengan meningkatnya nilai perusahaan (Tobin's Q) tersebut. Model persamaan serentak ini telah digunakan dalam beberapa penelitian terdahulu. Chen dan Steiner (1999) menggunakan prosedur persamaan serentak untuk menganalisis hubungan kepemilikan manajer, risiko perusahaan, kebijakan hutang dan kebijakan dividen. Hasil empiris mereka mendukung munculnya hubungan saling tergantung antara variabel yang diselidiki. Model persamaan serentak juga telah digunakan untuk menguji hubungan kepemilikan insider, analyst coverage dan Tobin's Q (Chen dan Steiner, 2000); hubungan kebijakan hutang, kepemilikan insider, dan dividen (Crutchley dan Hansen 1989; Jensen et al.1992; Tandelilin dan Wilberforce 2002; Miguel et al. 2005; Harjito, 2006; Harjito dan Nurfauziah, 2006); hubungan kepemilikan manajer, kebijakan hutang dan kepemilikan institusi (Bathala et al. 1984; Huson et al. 2005). Sistem persamaaan simultan penelitian ini adalah sebagai berikut:

$$
\begin{aligned}
\text { DEBT }= & \alpha_{1}+\beta_{1} \text { INSD }+\beta_{2} \text { DIVD }+\beta_{3} \text { FASET } \\
& +\beta_{4} \text { RISK }+\beta_{5} \text { PROFIT }+u_{1} \\
\text { INSD }= & \alpha_{2}+\beta_{6} \text { DEBT }+\beta_{7} \text { DIVD }+\beta_{8} \text { INST }+ \\
& \beta_{9} \text { RISK }+\beta_{10} \text { SIZE }+u_{2} \\
\text { DIVD }= & \alpha_{3}+\beta_{11} \text { INSD }+\beta_{12} \text { DEBT }+\beta_{13} \text { RISK }+ \\
& \beta_{14} \text { PROFIT }+\beta_{15} \text { GROWTH }+u_{3} \\
\text { TOBIN }= & \alpha_{4}+\beta_{16} \text { INSD }+\beta_{17} \text { DEBT }+\beta_{18} \text { DIVD } \\
& +\beta_{19} \text { SIZE }+\beta_{20} \text { PROFIT }+\beta_{21} \text { RISK }+u_{4}
\end{aligned}
$$

dengan:

$\alpha_{1}, \alpha_{2}, \alpha_{3}, \alpha_{1}:$ konstan

$\beta_{1} \ldots \beta_{21}$ : koefisien variabel $u_{1}, u_{2}, u_{3}, u_{4}$ : ralat

DEBT: rasio hutang; rasio antara jumlah hutang (hutang jangka pendek dan hutang jangka panjang) dengan nilai buku jumlah aset.

INSD:kepemilikan insider; rasio antara jumlah saham yang dimiliki oleh manajer dengan jumlah saham yang beredar.

DIVD: rasio pembayaran dividen; rasio antara dividen dengan keuntungan bersih.

TOBIN: (nilai pasar ekuitas + nilai buku jumlah hutang)/nilai buku jumlah aset

INST:kepemilikan institusi; rasio antara jumlah saham yang dimiliki oleh institusi dengan jumlah saham yang beredar.

FASET: rasio aset tetap; rasio antara aset tetap dengan jumlah aset.

GROWTH: pertumbuhan perusahaan keluarga, dihitung dari pertumbuhan penjualan selama sepuluh tahun.

RISK: risiko bisnis (volatilitas pendapataan) yang diukur dengan standar deviasi perbedaan pertama penghasilan operasi (operating income) selama sepuluh tahun.

SIZE: ukuran perusahaan keluarga yang dihitung dari logaritma jumlah aset.

PROFIT: rasio antara penghasilan operasi dengan jumlah aset.

Model Two-Stage Least Square (2SLS) ini merupakan model persamaan untuk menaksir parameter pada model persamaan simultan secara penuh. Artinya, model akan secara serentak menganalisis data yang diperlukan. Lain halnya model persamaan tunggal (ordinary least square), maka data dianalisis sendiri-sendiri oleh tiap persamaan yang hasilnya akan mengandung bias. Metode Two-Stage Least Squares (2SLS) merupakan metode yang dapat menghilangkan bias hasil yang terjadi jika menggunakan OLS.

\section{HASIL ANALISIS DAN PEMBAHASAN Deskriptif Statistik}

Analisis statistik deskriptif merupakan analisis yang menggambarkan karakteristik data-data yang digunakan dalam penelitian ini seperti terlihat pada Tabel 1.

Analisis ini penting untuk mengetahui karakteristik data-data dari sampel yang digunakan seperti nilai rata-rata (mean), median, nilai maksimum, nilai minimum, standar deviasi, dan jumlah observasi dari sampel yang diteliti. Karakteristik data berupa data sekunder 
yang berasal dari laporan keuangan perusahaan keluarga yang telah go public di Bursa Efek Indonesia tahun 2001 hingga tahun 2011. Jumlah populasi sebanyak 59 perusahaan keluarga, sedangkan jumlah sampelnya sebanyak 46 perusahaan keluarga yang memenuhi kriteria sebagai sampel penelitian.

\section{Pengujian Hipotesis}

Dijelaskan dimuka bahwa untuk menguji hipotesis pada penelitian ini digunakan model Two-Stage Least Squares (2SLS) dengan bantuan program E-Views 5. Hasil analisis data menggunakan model 2SLS tersebut dapat dilihat pada Tabel 2. Pada Tabel 2. tersebut terlihat nilai-nilai koefisien regresi baik untuk variabel dependen (tergantung) yang terdiri dari kepemilikan insider (INSD), kebijakan hutang (DEBT), kebijakan dividen (DIVD) dan nilai perusahaan (TOBIN) maupun variabel bebasnya yang terdiri dari kepemilikan institusi (INST), risiko bisnis (RISK), ukuran perusahaan (SIZE), tingkat profitabilitas (PROFIT), dan tingkat pertumbuhan (GROWTH).

Tabel 1: Statistik Deskriptif Variabel Tergantung dan Tidak Tergantung (bebas)

\begin{tabular}{lcccccc}
\hline Variabel & N & Rata-rata & Median & Minimum & Maksimum & Standar deviasi \\
\hline Variabel Tergantung & & & & & & \\
DEBT & 46 & 0,4217 & 0,5221 & 0,0225 & 0,9742 & 0,1264 \\
INSD & 46 & 0,3206 & 0,2013 & 0,1513 & 0,6912 & 0,0236 \\
DIVD & 46 & 0,1212 & 0,0910 & 0,0082 & 0,2610 & 0,0245 \\
TOBIN & 46 & 1,2002 & 0,5021 & 0,4314 & 3,8111 & 0,2813 \\
Variabel bebas: & & & & & & \\
INST & 46 & 0,1132 & 0,0231 & 0,0198 & 0,2334 & 0,0991 \\
FASET & 46 & 0,4219 & 0,0717 & 0,0257 & 0,6898 & 0,1880 \\
SIZE & 46 & 0,6921 & 0,5709 & 0,6409 & 0,7816 & 0,0511 \\
RISK & 46 & 0,0621 & 0,0013 & 0,0005 & 0,2113 & 0,0293 \\
PROFIT & 46 & 0,0962 & 0,0900 & 0,0340 & 0,2276 & 0,0867 \\
GROWTH & 46 & 0,0511 & 0,0050 & 0,0020 & 0,4316 & 0,1122 \\
\hline
\end{tabular}

Tabel 2: Hasil Regresi Model Two-Stage Least Square (2SLS)

\begin{tabular}{|c|c|c|c|c|}
\hline \multirow{2}{*}{$\begin{array}{l}\text { Variabel } \\
\text { tidak tergantung }\end{array}$} & \multicolumn{4}{|c|}{ Variabel tergantung } \\
\hline & DEBT & INSD & DIVD & TOBIN \\
\hline KONSTANTA & $0.2295^{* * * *}$ & 0,2346 & 0,2189 & 2,0049 \\
\hline & $(2,5344)$ & $(1,3041)$ & $(1,4618)$ & $(0,5191)$ \\
\hline DEBT & - & $-0,0284$ & $-0,1061$ & 0.2130 \\
\hline & & $(-0,4187)$ & $(-2.5723)^{* *}$ & $(2.1161)^{* *}$ \\
\hline INSD & - 0.2101 & & -0.0725 & 0.0276 \\
\hline & $(-0.7312)$ & & $(-0.8751)$ & $(0.0972)$ \\
\hline DIVD & -0.0201 & -0.0918 & - & -0.7214 \\
\hline & $(-2,5382) * *$ & $(-0.7394)$ & & $(-1.0835)$ \\
\hline INST & - & $\begin{array}{l}-0.2913^{* *} \\
(-2.4351)\end{array}$ & - & - \\
\hline FASET & $\begin{array}{l}0.5612^{* *} \\
(1.8219)\end{array}$ & & - & - \\
\hline SIZE & - & $\begin{array}{r}-0.2763 \\
(-0.3967)\end{array}$ & - & $\begin{array}{r}0.8853 \\
(0.3689)\end{array}$ \\
\hline RISK & $\begin{array}{r}0.4133 \\
(0.5461)\end{array}$ & $\begin{array}{r}-0.2542 \\
(-0.2944)\end{array}$ & $\begin{array}{r}0.1189 \\
(0.4512)\end{array}$ & $\begin{array}{r}0.3381 \\
(0.1284)\end{array}$ \\
\hline PROFIT & $\begin{array}{r}-0.2867 \\
(-0.5498)\end{array}$ & - & $\begin{array}{r}1.3287^{* * *} \\
(2.362)\end{array}$ & $\begin{array}{r}-0.1352 \\
(-0.7256)\end{array}$ \\
\hline GROWTH & & & $\begin{array}{r}-0.1892 \\
(-0.5922)\end{array}$ & - \\
\hline Nilai $R^{2}$ & 0.3514 & & & \\
\hline Durbin-Watson & 2.1152 & & & \\
\hline
\end{tabular}

Catatan:

${ }_{* * * *}$ signifikan pada tingkat signifikansi $1 \%$

** signifikan pada tingkat signifikansi $5 \%$

* signifikan pada tingkat signifikansi $10 \%$

Nilai statistik- $t$ dalam tanda kurung 
Tabel 2 di atas menunjukkan hasil analisis data dengan metode Two-Stage Least Squares yang menghubungkan variabel mekanisme pengurang masalah agensi dan kinerja perusahaan keluarga. Hasil analisis tersebut berupa nilai konstanta, koefisien variabel, nilai t-Statistic (dalam kurung), tingkat signifikansi (tanda bintang), nilai koefisien determinasi R (R-squared), dan nilai Durbin Watson bagi empat persamaan simultan pada penelitian ini. Keempat persamaan tersebut adalah persamaan kebijakan hutang (DEBT), kepemilikan insider (INSD), kebijakan dividen (DIVD), dan kinerja perusahaan (TOBIN). Hasil analisis tersebut menghaslkan persamaa sebagai berikut:

$$
\begin{aligned}
\text { DEBT }= & 0.2295-0.2101 \text { INSD }-0.0201 \text { DIVD } \\
& +0.5612 \text { FASET }+0.4133 \text { RISK }- \\
& 0.2867 \text { PROFIT }
\end{aligned}
$$

INSD $=0,2346-0,0284$ DEBT -0.0918 DIVD - 0.2913 INST - 0.2542 RISK 0.2763 SIZE

$\begin{aligned} \text { DIVD }= & 0,2189-0.0725 \text { INSD }-0,1061 \\ & \text { DEBT }+0.1189 \text { RISK }+1.3287 \\ & \text { PROFIT }-0.1892 \text { GROWTH }\end{aligned}$

TOBIN $=2,0049+0.0276$ INSD +0.2130

DEBT -0.7214 DIVD +0.8853 SIZE -0.1352 PROFIT + 0.3381 RISK

Pengujian secara simultan atau serentak hubungan substitusi antara kebijakan hutang, kepemilikan insider dan kebijakan dividen dalam mekanisme pengawasan masalah agensi dalam kajian ini sudah menggunakan pengujian Newey-West untuk mengatasi masalah heteroskedastisitas yang sering timbul apabila datanya adalah cross section (Gujarati, 2003) dan sudah terbebas dari gejala multikolinearitas. Namun demikian, nilai koefisien determinasi ( $\mathrm{R}$ kuadrat) yang kecil $(0,3514)$ menunjukkan bahwa sumbangan variabel penjelas hanya sebesar $35,14 \%$, sedangkan selebihnya sebesar $64,86 \%$ dijelaskan oleh variabel penjelas lain yang tidak ada dalam model. Berikut ini dibahas tiap-tiap persamaan yang dianalisis untuk mengetahui hubungan substitusi antara kebijakan hutang, kepemilikan insider dan kebijakan dividen serta pengaruhnya terhadap kinerja perusahaan keluarga yang dijadikan sampel.

\section{Persamaan Hutang}

Salah satu mekanisme untuk mengurangi konflik atau masalah agensi adalah dengan cara bonding, yaitu manejer mengikatkan diri kepada perusahaan untuk bekerja sesuai dengan keinginan prinsipal. Mekanisme bonding dapat dilakukan dengan 2 cara, yaitu dengan cara meningkatkan hutang atau meningkatkan pembayaran dividen. Hasil analisis regresi 2SLS untuk variabel tergantung hutang (DEBT) ditunjukkan dalam Tabel 2 pada kolom kedua. Variabel bebas yang mempengaruhi persamaan hutang tersebut meliputi variabel kepemilikan insider, kebijakan dividen, aktiva tetap dan risiko bisnis. Variabel kepemilikan insider (INSD) mempunyai hubungan negatif tetapi tidak signifikan dengan hutang $(b=-0,2101 ; \mathrm{t}$ $=-0,7312$ ). Hasil tersebut sebetulnya menunjukan adanya hubungan substitusi antara hutang dan kepemilikan insider karena memiliki koefisien negatif, tetapi hubungan tersebut tidak signifikan. Oleh karena itu, secara statistik menunjukkan bahwa tidak terdapat hubungan substitusi secara signifikan antara hutang dan kepemilikan insider dalam mekanisme pengawasan masalah agensi. Kepemilikan insider tidak secara signifikan dapat menggantikan peranan hutang dalam pengawasan masalah agensi. Oleh karena itu, hipotesis pertama yang menyatakan terdapat hubungan substitusi antara hutang dengan kepemilikan insider pada perusahaan keluarga di Indonesia tidak terbukti. Hasil penemuan penelitian ini bertentangan atau tidak konsisten dengan beberapa hasil kajian yang lalu (Friend and Lang 1988), (Jensen et al. 1992), (Chen dan Steiner, 1999), (Tandelilin dan Wilberforce 2002) dan Miguel et al. (2005). Namun demikian, hasil penelitian ini sudah menunjukkan hasil yang sesuai dengan penelitian terdahulu yaitu adanya hubungan negatif antara kepemilikan insider dan hutang, hanya saja ditemukan hasil yang tidak signifikan (Harjito dan Nurfauziah, 2006).

Mekanisme bonding yang kedua untuk mengurangi masalah agensi adalah dengan meningkatkan pembayaran dividen. Mekanisme peningkatan pembayaran dividen ini semestinya dapat menggantikan peranan kebijakan hutang perusahaan dalam mengurangi masalah agensi. Berdasarkan hasil analisis menunjukkan bahwa koefisien pengaruh kebijakan dividen (DIVD) terhadap hutang (DEBT) adalah negatif dan signifikan yaitu $(\mathrm{b}=$ $0.0201 ; \mathrm{t}=-2,5382)$. Koefisien regresi yang negatif dan signifikan ini menunjukkan hubungan negatif antara dividen dengan hutang. Artinya, kebijakan pembayaran dividen berpengaruh negatif signifikan terhadap 
kebijakan kebijakan hutang. Oleh karena itu, peningkatan pembayaran dividen akan menurunkan penggunaan jumlah hutang yang ada di dalam perusahaan keluarga. Hubungan terbalik atau berlawanan tersebut menunjukkan adanya hubungan substitusi atau saling mengganti antara kebijakan hutang dan kebijakan dividen dalam peranannya untuk mengurangi masalah agensi. Maksudnya, peningkatan pembayaran dividen sebagai mekanisme pengurang masalah agensi dapat digunakan untuk menggantikan peranan hutang dalam pengawasan masalah agensi bagi perusahaan keluarga di Indonesia. Berdasarkan hasil tersebut, maka hipotesis kedua $(\mathrm{H} 2)$ yang menyatakan bahwa terdapat hubungan substitusi antara kebijakan dividen dengan kebijakan hutang dapat dibuktikan. Hasil penelitian ini mendukung kajian yang dilakukan oleh Chen dan Steiner (1999) dan Jensen et al. (1992). Chen dan Steiner (1999) menemukan hubungan negatif dan signifikan antara pembayaran dividen dengan kebijakan hutang yang penelitiannya dilakukan di Amerika bagi 785 sampel perusahaan yang terdaftar di Bursa Saham New York. Di samping itu, Jensen et al. (1992) juga menemukan hubungan negatif dan signifikan antara pembayaran dividen dengan penggunaan hutang bagi 632 perusahaan yang juga terdaftar di Bursa Saham New York.

\section{Persamaan Kepemilikan Insider}

Analisis bagi persamaan kepemilikan insider dimaksudkan bahwa kepemilikan insider (INSD) bertindak sebagai variabel tergantung, sedangkan variabel lain yaitu kebijakan hutang (DEBT) dan dividen (DIVD) sebagai variabel bebas yang utama, sedangkan variabel independen lain bertindak sebagai variabel kontrol terhadap variabel kepemilikan insider, yaitu variabel kepemilikan institusi (INST), ukuran perusahaan (SIZE) dan risiko bisnis (RISK). Koefisien variabel hutang (DEBT) menunjukkan tanda negatif yaitu $(\mathrm{b}=-0.0284 ; \mathrm{t}=-$ 0.4187). Hal ini menunjukkan bahwa adanya hubungan negatif tetapi tidak signifikan antara kebijakan hutang dengan kepemilikan insider. Hubungan negatif antara hutang dengan kepemilikan insider ini mengindikasikan bahwa peningkatan hutang akan menyebabkan penurunan peranan kepemilikan insider dalam mekanisme pengurang masalah agensi. Hubungan ini juga menunjukkan bahwa peranan kepemilikan insider bagi perusahaan keluarga di Indonesia dapat menggantikan peranan hutang dalam mekanisme pengawasan masalah agensi meskipun tidak efektif. Oleh karena itu, kedua mekanisme tersebut harus dilakukan secara bersama-sama. Tidak signifikannya hubungan antara kepemilikan insider dan hutang ini tidak mendukung hipotesis pertama (H1) yang menyatakan terdapat hubungan substitusi antara kebijakan hutang dengan kepemilikan insider sebagai mekanisme pengawasan masalah agensi bagi perusahaan keluarga di Indonesia. Penelitian terdahulu yang dilakukan oleh Jensen et al.(1992) dan Miguel et al. (2005) tidak mendukung hasil kajian ini. Namun demikian, kajian Huson et al. (2005) dan Harjito dan Nurfauziah (2006) menemukan hasil yang mendukung kajian ini. Kajian mereka menemukan bahwa kepemilikan manajer (kepemilikan insider) tidak dapat menggantikan peranan hutang dalam mekanisme pengawasan masalah agensi.

Mekanisme pengawasan masalah agensi melalui bonding dapat dilakukan dengan meningkatkan pembayaran dividen oleh perusahaan keluarga di Indonesia. Tabel 2 menunjukkan bahwa rasio pembayaran dividen (DIVD) mempunyai hubungan negatif tetapi tidak signifikan dengan kepemilikan insider (b $=-0.0918 ; \mathrm{t}=-0.7394)$. Hasil ini menunjukkan bahwa pembayaran dividen tidak mempunyai hubungan terbalik yang signifikan dengan kepemilikan insider dalam peranan pengawasan masalah agensi pada perusahaan keluarga di Indonesia. Antara kebijakan pembayaran dividen dan kepemilikan insider tidak terdapat hubungan substitusi secara efektif dalam peranan mekanisme pengawasan masalah agensi pada perusahaan keluarga di Indonesia. Dengan demikian, peranan kepemilikan insider dalam mekanisme pengawasan masalah agensi tidak dapat digantikan dengan peningkatan pembayaran dividen pada perusahaan keluarga di Indonesia. Hipotesis ketiga (H3) yang menyatakan bahwa terdapat hubungan substitusi antara kepemilikan insider dengan pembayaran dividen di perusahaan keluarga tidak terbukti.

Hubungan negatif yang tidak signifikan antara peningkatan pembayaran dividen dan kepemilikan insider dalam mekanisme pengawasan masalah agensi berimplikasi bahwa kebijakan pembayaan dividen tidak dapat menggantikan peranan kepemilikan insider dalam mengurangi masalah agensi pada 
perusahaan keluarga di Indonesia. Hasil penelitian ini tidak mendukung kajian Chen dan Steiner (1999), namun mendukung kajian yang dilakukan oleh Jensen et al. (1992) dan Harjito dan Nurfauziah (2006). Jensen et al. (1992) menemukan hubungan negatif tetapi tidak signifikan antara pembayaran dividen dengan kepemilikan insider. Berdasarkan hasil kajian tersebut, peranan kepemilikan insider dalam mekanisme pengawasan masalah agensi tidak dapat digantikan dengan meningkatkan pembayaran dividen. Hubungan antara pembayaran dividen dengan kepemilikan insider dalam mekanisme pengawasan masalah agensi bersifat saling melengkapi. Sementara, Harjito dan Nurfauziah (2006) menemukan bahwa dividen tidak dapat menggantikan peranan kepemilikan insider dalam mengurangi masalah agensi bagi perusahaan keluarga di Indonesia.

\section{Persamaan Dividen}

Mekanisme pengawasan masalah agensi melalui peningkatan pembayaran dividen merupakan mekanisme bonding untuk menguragi masalah agensi. Dalam bagian ini dibahas hubungan antara variabel mekanisme pengawasan masalah agensi yaitu dividen sebagai variabel tergantung (DIVD), sedangkan variabel mekanisme pengawasan yang lain yaitu kepemilikan insider (INSD) dan kebijakan hutang (DEBT) diposisikan sebagai variabel bebas. Adapun variabel independen yang lain seperti risiko bisnis, tingkat profitabilitas, dan tingkat pertumbuhan digunakan sebagai variabel kontrol. Tabel 2 menunjukkan hasil regresi dimana dividen (DIVD) sebagai variabel tergantung. Hasil tersebut menunjukkan bahwa koefisien variabel rasio hutang (DEBT) dalam persamaan dividen tersebut adalah negatif dan signifikan $(b=-0.1061 ; t=-2.5723)$. Keadaan ini berarti bahwa dalam peranan pengawasan masalah agensi pada perusahaan keluarga di Indonesia adanya peningkatan rasio hutang sebanyak $1 \%$ akan menurunkan rasio pembayaran dividen sebanyak $0.1061 \%$. Hubungan negatif yang signifikan ini menunjukkan terdapat hubungan substitusi antara kebijakan hutang dengan kebijakan pembayaran dividen dalam mekanisme pengawasan masalah agensi pada perusahaan keluarga di Indonesia. Peranan dividen sebagai mekanisme untuk mengurangi masalah agensi akan menurun dengan meningkatnya tingkat hutang. Hasil penelitian ini bertentangan dengan hasil peneli- tian Tendelilin dan Wilberforce (2002). Mereka menemukan hubungan positif dan signifikan antara pembayaran dividen dengan hutang. Namun, hasil penelitian ini mendukung sepenuhnya penelitian yang dilakukan oleh Jensen et al. (1992) dan Chen dan Steiner (1999). Mereka menemukan hasil yang sama dengan penelitian ini, meskipun penelitiannya dilakukan di Bursa Saham N ew York.

Kepemilikan insider (INSD) juga mempunyai koefisien negatif dalam persamaan dividen tetapi tidak signifikan $(b=-0.0725 ; \mathrm{t}=$ $-0,8751)$. Hal ini menunjukkan bahwa peningkatan kepemilikan insider akan menurunkan tingkat pembayaran dividen meskipun tidak signifikan. Sebetulnya, peningkatan kepemilikan insider dimaksudkan untuk meningkatkan keselarasan atau persetujuan antara kepentingan pemegang saham dengan manajer dalam meningkatkan keuntungan perusahaan. Hasil ini juga menunjukkan bahwa mekanisme pengawasan masalah agensi di dalam sebuah perusahaan keluarga melalui peningkatan kepemilikan insider tidak dapat menggantikan peranan kebijakan pembayaran dividen untuk mengurangi masalah agensi. Peningkatan pembayaran dividen sebagai kebijakan keuangan tidak dapat diganti peranannya oleh kepemilikan insider sebagai kebijakan bukan keuangan dalam mekanisme pengawasan masalah agensi. Oleh karena itu, peningkatan jumlah kepemilikan insider ini tidak memungkinkan untuk mengurangi kebijakan pembayaran dividen. Hasil penelitian ini mendukung hasil penelitian Tandelilin dan Wilberforce (2002) dan Miguel et al. (2005). Kedua kajian ini menemukan tidak terdapat hubungan substitusi antara kepemilikan insider dan tingkat pembayaran dividen. Namun demikian, hasil kajian ini tidak mendukung hasil kajian Chen dan Steiner (1999), Jensen et al. (1992), dan Rozeff (1982). Mereka menemukan bukti bahwa peningkatan kepemilikan insider akan menurunkan pembayaran dividen secara signifikan.

\section{Persamaan Kinerja Perusahaan}

Penelitian ini ingin mengetahui hubungan antara mekanisme pengawasan masalah agensi dengan kinerja perusahaan keluarga di Indonesia. Hubungan diantara mekanisme pengawasan agensi (pengurang masalah agensi) yang terdiri dari kebijakan hutang, kebijakan kepemilikan insider dan kebijakan dividen sudah dibahas di sub bab sebelumnya. Bagian 
ini membahas bagaimana pengaruh hubungan masing-masing mekanisme pengawasan agensi tersebut terhadap kinerja perusahaan keluarga yang diproksi dengan nilai Tobin's Q (TOBIN). Besarnya nilai Tobin's Q diperoleh dari penjumlahan nilai buku total hutang ditambah nilai pasar ekuitas dibagi nilai buku total aktiva. Apabila terdapat hubungan substitusi atau saling menggantikan diantara variabelvariabel pengurang masalah agensi dalam peranannya untuk mengurangi masalah agensi, maka kinerja perusahaan keluarga akan meningkat. Di samping itu, pembahasan juga menganalisis hubungan langsung antara variabel pengurang masalah agensi dengan kinerja perusahaan keluarga (TOBIN). Berdasarkan hasil analisis, pengaruh variabel mekanisme pengawasan masalah agensi yang terdiri dari hutang, kepemilikan insider dan dividen, serta variabel-variabel tidak tergantung lainnya terhadap kinerja (nilai) perusahaan (TOBIN) dapat dilihat pada nilai koefisien setiap variabel tersebut pada Tabel 2 di atas.

Tabel 2 menunjukkan bahwa pengaruh variabel rasio hutang (DEBT) sebagai salah satu unsur dalam mekanisme bonding terhadap kinerja atau nilai perusahaan (TOBIN) adalah positif dan signifikan $(b=0.2130 ; t=2.1161)$. Hubungan atau pengaruh positif ini menunjukkan bahwa peningkatan hutang akan meningkatkan kinerja perusahaan keluarga di Indonesia. Meningkatnya hutang akan memberi dukungan dana yang besar bagi perusahaan keluarga untuk bekerja lebih baik. Hutang yang tinggi menggerakan roda kegiatan perusahaan keluarga lebih bergairah. Sesuai dengan teori pecking order, maka kebutuhan dana yang diperlukan haruslah dipenuhi dari hutang terlebih dahulu, kemudian kalau masih kurang baru dipenuhi dari sumber ekuitas atau modal sendiri (Myers dan Majluf, 1984). Meskipun demikian, meningkatnya hutang akan meningkatkan risiko kebangkrutan dan kesulitan keuangan perusahaan. Kesulitan perusahaan ini akan mengurangi keuntungan perusahaan. Oleh karena itu, menurunnya keuntungan menyebabkan berkurangnya dana internal (berasal dari laba ditahan) yang akan digunakan untuk mengembangkan perusahaan keluarga, sehingga kekurangan kebutuhan dana tersebut dipenuhi dari hutang. Perusahaanperusahaan di Indonesia, termasuk perusahaan keluarga masih sangat tergantung terhadap hutang dalam mengembangkan usahanya. Tingginya hutang akan meningkatkan hasil operasi perusahaan yang pada akhirnya kinerja perusahaan akan meningkat.

Variabel mekanisme pengawasan masalah agensi berupa kepemilikan insider (INSD) memiliki pengaruh positif tetapi tidak signifikan terhadap nilai atau kinerja perusahaan $(b=0.0276 ; t=0.0972)$. Keadaan ini menunjukkan bahwa peningkatan jumlah saham yang dipegang oleh pengelola atau manajer yang lain kemungkinan akan meningkatkan kinerja perusahaan keluarga, meskipun tidak signifikan. Fenomena ini cukup menarik karena penelitian ini adalah dikhususkan bagi perusahaan keluarga dimana mayoritas kepemilikan perusahaan adalah dipegang anggota keluarga. Hasil analisis menunjukkan bahwa meningkatnya kepemilikan keluarga tidak berpengaruh positif secara signifikan terhadap kinerja perusahaan. Hal ini mungkin saja terjadi, karena meningkatnya kepemilikan keluarga sifatnya tidak merata ke semua anggota keluarga sehingga hanya sebagian kecil anggota keluarga yang memiliki saham mayoritas. Oleh karena itu, kemungkinan terjadi konflik atau masalah agensi berkaitan dengan kepemilikan tersebut. Konflik agensi yang terjadi bukan konflik antara pemilik perusahaan (prinsipal) dengan manajer atau pengelolanya (agen), tetapi konflik yang terjadi adalah konflik antara pemegang saham mayorias dengan pemegang saham minoritas. Dengan demikian, adanya konflik tersebut maka peningkatan kepemilikan insider tidak efektif meningkatkan kinerja perusahaan keluarga di Indonesia atau peningkatan kepemilikan insider tidak meningkatkan kinerja perusahaan secara signifikan. Hasil penelitian ini tidak mendukung penelitian Jensen dan Meckling (1976). Mereka menegaskan bahwa kepemilikan yang terkonsentrasi akan meningkatkan nilai perusahaan karena kepemilikan terkonsentrasi sebagai mekanisme untuk mengurangi masalah agensi. Sementara itu, kepemilikan perusahaan keluarga biasanya adalah terkonsentrasi pada keluarga tertentu, sehingga sesuai temuan Jensen dan Meckling (1976) maka hasil penelitian ini tidak mendukungnya. Sedangkan kajian Chen dan Steiner (2000) menemukan bahwa kepemilikan insider mempunyai hubungan positif dan signifikan dengan Tobin's Q. Namun, mereka menemukan hubungan yang tidak linier antara kepemilikan insider dengan Tobin's Q. Artinya bahwa pada waktu kepemilikan meningkat sampai batas maksimal, maka nilai TOBIN juga meningkat. Namun 
ketika rasio kepemilikan insider melebihi $28.83 \%$ diketahui adanya hubungan negatif yang berarti meningkatnya kepemilikan insider justru menurunkan nilai perusahaan.

Mekanisme bonding kedua dalam pengawasan masalah agensi adalah peningkatan pembayaran dividen. Variabel pembayaran dividen (DIVD) dalam kajian ini memiliki hubungan negatif tetapi tidak signifikan dengan nilai perusahaan atau Tobin's Q (b $=-0.7214$; dan $\mathrm{t}=-1.0835)$. Hubungan negatif ini menunjukkan bahwa peningkatan pembayaran dividen memberi kesan negatif kepada investor tentang keadaan perusahaan. Semestinya, peningkatan pembayaran dividen mempunyai signal positif karena pembayaran dividen yang meningkat menunjukkan bahwa perusahan meningkat kinerjanya. Hal ini bisa saja terjadi karena kemungkinan adanya manipulasi keadaan yang terjadi di dalam perusahaan keluarga yang bersangkutan. Maksudnya bahwa pembayaran dividen yang meningkat dimaksudkan untukmemberi kesan positif kepada pasar. Namun ternyata terjadi sebaliknya, peningkatan pembayaran dividen justru memberikan kesan negatif. Mungkin saja, keadaan perusahaan keluarga yang kurang baik sehingga pasar merespon negatif. Dengan demikian, pembayaran dividen yang tinggi ternyata belum tentu menunjukkan tanda bagi investor bahwa masalah agensi dapat dikurangi. Investor-investor yang ada di Bursa Efek Indonesia tidak sepenuhnya mempercayai adanya signal meningkatnya pembayaran dividen, sehingga harga pasar saham tidak meningkat secara signifikan. Dengan demikian, peningkatan pembayaran dividen sebagai mekanisme pengurang masalah agensi belum digunakan secara signifikan sebagai alat pengawasan oleh pemilik untuk mengurangi masalah agensi.

\section{PENUTUP}

Penelitian ini bertujuan melakukan kajian mengenai hubungan agensi dan kinerja dalam melakukan tata kelola perusahaan keluarga secara efektif dan efisien dalam mengurangi masalah agensi. Penelitian ini dilakukan terhadap sampel perusahaan keluarga yang terdaftar di Bursa Efek Indonesia tahun 2001 sampai tahun 2011. Penelitian difokuskan pada variabel mekanisme pengurang atau pengawasan masalah agensi yang terdiri dari kebijakan hutang, kepemilikan insider dan kebijakan dividen kaitannya dengan kinerja perusahaan keluarga. Diantara mekanismemekanisme pengawasan masalah agensi tersebut dikaji ada tidaknya hubungan substitusi atau hubungan komplementer antara kebijakan hutang, kepemilikan insider dan kebiß̆ kan dividen dalam peranan pengawasan masalah agensi pada perusahaan keluarga di Indonesia. Hubungan substitusi ditunjukkan dengan adanya hubungan negatif diantara variabel pengurang masalah agensi, sementara hubungan komplementer ditunjukkan dengan adanya hubungan positif diantara variabel pengurang masalah agensi tersebut. Adanya hubungan substitusi tersebut diharapkan dapat mengurangi masalah agensi, dan pada akhirnya dapat meningkatkan kinerja atau nilai perusahaan yang diproksi dengan nilai Tobin's Q. Untuk mencapai tujuan penelitian, maka data dianalisis menggunakan metode TwoStage Least Square (2SLS).

Berdasarkan hasil analisis dan pembahasan yang dilakukan dapat disimpulkan beberapa hal sebagai berikut, 1) Tidak terdapat hubungan substitusi antara kebjakan hutang dengan kepemilikan insider dalam peranan pengawasan masalah agensi pada perusahaan keluarga di Indonesia. Hal ini ditunjukkan oleh adanya koefisien regresi yang negatif tetapi tidak signifikan antara kebijakan hutang dengan kepemilikan insider. Seperti halnya hubungan antara kepemilikan insider dengan kebijakan dividen, sebenarnya koefisien yang negatif hubungan antara kebijakan hutang dengan kepemilikan insider tersebut telah menunjukkan hubungan substitusi, namun tidak efektif. Artinya hubungan kedua variabel tersebut tidak mencapai tujuan yang optimal dalam peranan substitusi untuk mengurangi masalah agensi pada perusahaan keluarga di Indonesia. 2) Terdapat hubungan substitusi yang signifikan antara kebijakan hutang dengan kebijakan pembayaran dividen dalam peranan pengawasan masalah agensi pada perusahaan keluarga di Indonesia. Kesimpulan ini didasarkan pada adanya hubungan negatif dan signifikan antara variabel hutang dengan dividen. Hubungan yang negatif tersebut menunjukkan bahwa apabila kebijakan hutang meningkat maka kebijakan dividen menurun. Oleh karena kedua variabel tersebut sebagai vaiabel mekanisme pengawasan (pengurang) masalah agensi, maka kedua variabel tersebut dapat substitusi dalam peranannya melakukan pengawasan masalah agensi pada perusahaan 
keluarga di Indonesia. 3) Tidak terdapat hubungan substitusi antara kepemilikan insider dengan pembayaran dividen dalam peranan pengawasan masalah agensi pada perusahaan keluarga di Indonesia. Hal ini ditunjukkan adanya koefisien regresi yang negatif tetapi tidak signifikan antara kepemilikan insider dengan pembayaran dividen. Sebenarnya koefisien yang negatif tersebut telah menunjukkan hubungan substitusi, namun tidak efektif. Artinya hubungan kedua variabel tersebut tidak mencapai tujuan yang optimal dalam peranan substitusi untuk mengurangi masalah agensi pada perusahaan keluarga di Indonesia. 4) Hubungan atau pengaruh kebijakan hutang terhadap kinerja perusahaan keluarga di Indonesia adalah positif dan signifikan. Hal ini menunjukan bahwa, semakin besar hutang yang digunakan oleh perusahaan meningkatkan kinerja perusahaan. Meskipun hutang ini mengandung risiko, tetapi ternyata besarnya hutang tersebut akan men-generate keuntungan yang besar dan akhirnya meningkatkan kinerja perusahaan. Sementara itu, kepemilikan insider juga memiliki hubungan atau pengaruh yang positif tetapi tidak signifikan terhadap kinerja perusahaan keluarga di Indonesia. Meningkatnya kepemilikan insider mungkin justru membuat masalah agensi, yaitu konflik antara kepemilikan mayoritas dan minoritas di dalam perusahaan keluarga. Oleh karena itu, meskipun peningkatan kepemilikan insider dapat meningkatkan prestasi atau kinerja perusahaan namun peningkatan prestasi tersebut kurang efektif. Terakhir, hubungan atau pengaruh kebijakan dividen terhadap kinerja perusahaan dalam peranan pengawasan masalah agensi pada perusahaan keluarga di Indonesia ternyata memiliki koefisien negatif meskipun tidak signifikan. Keadaan ini menunjukkan bahwa peningkatan pembayaran dividen justru akan menurunkan prestasi atau kinerja perusahaan keluarga di Indonesia. Hal ini kemungkinan disebabkan karena adanya peningkatan dividen ini berarti mengurangi sumber dana internal yang dapat digunakan untuk meningkatkan prestasi atau kinerja perusahaan.

Beberapa keterbatasan dan saran adalah sebagai berikut, 1) Penelitian ini hanya menggunakan sampel dari perusahaan perusahaan keluarga yang terdaftar di Bursa Efek yang jumlahnya hanya 46 perusahaan, sehingga hasil penelitian tidak dapat menjadi gambaran menyeluruh mengenai peranan mekanisme pengawasan atau pengurang masalah agensi pada semua perusahaan keluarga di Indonesia. Apabila menginginkan gambaran yang lebih luas tentang peranan variabel pengurang masalah agensi terhadap mekanisme pengawasan masalah agensi, maka penelitian selanjutnya sebaiknya menggunakan sampel dari seluruh sektor perusahaan keluarga yang ada di Indonesia. 2) Data dalam penelitian ini berupa data cross sectional dari rata - rata data selama sepuluh tahun yaitu tahun 2001 2011 sehingga sampel yang diperoleh hanya sedikit dan tidak menunjukkan naik atau turunnya data selama periode penelitian. Oleh karena itu, penelitian selanjutnya dapat menggunakan data panel yaitu gabungan data time series dan cross sectional yang dianalisis dengan model pool data analysis, sehingga akan terlihat adanya random effect atau fixed effect-nya. 3) Dilihat dari nilai R-squared yang masih kecil pada penelitian ini, maka penelitian selanjutnya sebaiknya memperbanyak variabel independennya agar hubungan agensi diantara variabel mekanisme pengurang masalah agensi lebih jelas.

\section{DAFTAR PUSTAKA}

Bathala, C.T., Moon, K.P. dan Rao, R.P. 1994. Managerial ownership, debt policy, and the impact of institutional holdings: An agency perspective Financial Management 23 (3): 38-50.

Borokhovich, K. A., Brunarski, K. R., Harman, Y. dan Kehr, J. B. 2005. Dividends, corporate monitors and agency costs. The Financial Review 40(1): 37-65.

Chen, Xia., Cheng, Qiang dan Dai, Zhonglan. 2006. Agency Problems in Family Firms: Evidence from CEO Turnover and Fim Valuation. Working Paper at the Accounting Research Conference of the Univiversities of British Colombia: 1-41.

Chen, C. dan Steiner, T. 1999. Managerial ownership and agency conflicts: A nonlinear simultaneous equation analysis of managerial ownership, risk taking, debt policy, and dividend policy. Financial Review 34: 119-136.

Chen, C. dan Steiner, T. 2000. Tobin's Q, managerial ownership, and analyst coverage. Journal of Economics and Business52: 365 -382. 
Crutchley, C.E. dan Hansen, R.S. 1989, A test of the agency theory of managerial ownership, corporate leverage, and corporate dividends. Financial Management 18: 36-46.

Douglas, A.V.S. 2002. Capital structure and the control of managerial incentives. Journal of Corporate Finance. 8: 287-311.

Fama, E. F. 1980. Agency problem and the theory of the firm. Journal of Political Economy 88: 288-307.

Friend, I. dan Lang, L.H.P. 1988. An empirical test of the impact of managerial self interest on corporate capital structure. The Journal of Finance 43(2): 271-281.

Gujarati, D. N. 2003. Basic Econometrics. McGraw Hill Higher Education. Ed. Ke-4. Singapore.

Harjito, D. A. 2006. Substitution Relationship Between the Agency Problem Control Mechanisms in Malaysia: Simultaneous Equation Analysis, Jurnal Siasat Bisnis, Vol. 11: 117 - 127.

Harjito, D. A. dan Nurfauziah. 2006. Hubungan Kebijakan Hutang, Insider Ownership dan Kebijakan Dividen dalam Mekanisme Pengawasan Masalah Agensi di Indonesia, JAAI, Vol. 10: 161-182.

Harris, M. dan Raviv, A. 1990. Capital structure and the informational role of debt. Journal of Finance 45: 321-349.

Huson Joher, Mohd Ali dan Nazrul. 2005. The impact of ownership structure on corporate debt policy: Two stage least square simultaneous model approach. Asian Financial Association Conference Proceeding. Kuala Lumpur.

Jensen dan Smith. 1985. Stockholder, manager and creditor interests: Applications of agency theory. American Economic Review 76: 323-339.

Jensen, G., Solberg, D. dan Zorn, T. 1992. Simultaneous determination of insider ownership, debt and dividend policies. Journal of Financial and Quantitative Analysis 27(2): 247-263.

Jensen, M. C. 1986. Agency costs of free cash flow, corporate finance and takeovers.
American Economic Review 76: 323339.

Jensen, M.C. dan Meckling, W.H. 1976. Theory of the firm: managerial behavior, agency costs and ownership structure. Journal of Financial Economics 3: 305-360.

Maury, B. 2005. Family ownership and firm performance: Empirical evidence from Western European corporations. Journal of Corporate Finance 12: 321-341.

Miguel, A., Pindado, J. dan de la Torne, C. 2005. How do entrenchment and expropriation phenomena affect control mechanism?. Corporate Governance: An International Review 13(4): 1-29.

Morck, R. and Yeung, B. 2003. Agency Problems in Large Family Business Groups. Entrepreneurship: Theory and Practice 27 (4): 367-382.

Myers, S.C. 1977. Determinants of corporate borrowing. Journal of Financial Economics 19: 147-176.

Myers, S. C dan Majluf, N. S. 1984. Corporate financing and investment decisions when firms have information that investors do not have. Journal of Financial Economics 13: 187-221.

Pomerleano, M. 1998. The east Asia crisis and corporate finances: The untold microeconomic story. Emerging Market Quarterly: 14-27.

Rozeff, M. 1982. Growth, beta, and agency costs as determinants of dividend payout ratios. Journal of Financial Research 3: 249-259.

Schulze, W.S., Lubaktin, M.H., Dino, R.N. dan Buchholtz, A.K. 2001. Agency Relationship in Family Firms: Theory and Evidence. Organization Science 12 (2): 99-116.

Tandelilin, E. dan Wilberforce, T. 2002. Can debt and dividend policies substitute insider ownership in controlling equity agency conflict?. Gadjah Mada International Journal of Business 4: 31-43.

Yong, O 1997. Pengantar Teori Kewangan. Dewan Bahasa dan Pustaka. Kuala Lumpur. 